\title{
Current level of infective endocarditis prevention awareness among dentists and patients with artificial valves
}

\author{
Aktualny stan wiedzy dentysty oraz pacjenta ze sztuczną zastawką \\ dotyczący profilaktyki infekcyjnego zapalenia wsierdzia
}

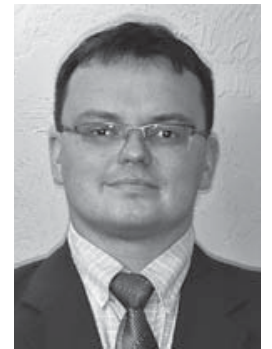

\author{
Bartłomiej Pawlus ${ }^{1}$, Ewa Markowicz-Pawlus² ${ }^{2}$ Miloš Špidlen ${ }^{1}$ \\ ${ }^{1}$ Department of Orthodontics, Clinic of Dental Medicine, Medical Faculty of Palacky University, Olomouc, Czech Republic \\ ${ }^{2}$ Department of Cardiology, Congenital Heart Diseases and Electrotherapy, Division of Cardiology SUM, Silesian Center \\ for Heart Diseases, Poland
}

Kardiochirurgia i Torakochirurgia Polska 2012; 9 (4): 420-423

\begin{abstract}
Background: For many years, the prophylactic use of antibiotics in patients with heart diseases associated with a high risk of infective endocarditis (IE) was a common practice. In patients with artificial valves, the morbidity and mortality in the occurrence of IE reaches several dozen percent. Currently, the only treatments that require IE prophylaxis are dental procedures. Aim of the study: The aim of this study was to assess IE prevention awareness among dentists and patients with artificial valves.

Material and methods: We analyzed 48 patients (26 men and 22 women) after artificial valve implantation. The time since their surgery was $4.5 \pm 1.5$ years. Twenty-nine patients (67.4\%) had an artificial aortic valve, 19 (39.6\%) had a mitral valve. Mean age was $67.5 \pm 6.2$ years. Information on IE prophylaxis was obtained during routine outpatient visits. Questionnaires concerning IE prophylaxis were distributed among 35 dentists. Results: Forty-one patients (85.4\%) were aware of the need for IE prophylaxis, of whom 28 (68.2\%) identified only dental procedures as requiring IE prevention, while 14 patients (34.1\%) included gastroscopy, colonoscopy, and coronarography in this category, and 18 patients (43.9\%) identified amoxicillin as the recommended antibiotic. Fifty-four (98.2\%) dentists indicated that patients with artificial valves require IE prophylaxis, while $41 / 55$ (74.5\%) indicated amoxicillin or ampicillin as the recommended prophylactic agent. All the dentists saw the need for IE prophylaxis before tooth extraction; 50 (90.9\%) - during root canal treatment; 50 (90.9\%) - during procedures around the gingiva. 10 respondents (18.2\%) did not recommend IE prophylaxis before tooth implantation; 10 (18.2\%) - before removing tartar. Conclusions: The large majority of patients with artificial heart valves are aware of the need for IE prevention. The knowledge
\end{abstract}

\section{Streszczenie}

Wstęp: Przez wiele lat profilaktyczne stosowanie antybiotyków u pacjentów z chorobami serca związanymi z dużym ryzykiem rozwoju infekcyjnego zapalenia wsierdzia (IZW) było powszechną praktyką kardiologiczną i dentystyczną. Jednocześnie rośnie populacja chorych ze sztuczną zastawką, wśród których chorobowość i śmiertelność przy wystąpieniu IZW sięgają kilkudziesięciu procent. Obecnie jedynymi zabiegami wymagającymi profilaktyki są zabiegi dentystyczne, wiążące się z przerwaniem ciągłości śluzówki jamy ustnej.

Materiat i metody: Badaniem objęto 48 pacjentów (26 mężczyzn i 22 kobiety) po implantacji sztucznej zastawki. Średni czas po implantacji zastawki wynosił 4,5 $\pm 1,5$ roku. Dwudziestu dziewięciu pacjentów $(67,4 \%)$ miało sztuczną zastawkę aortalną, 19 (39,6\%) - sztuczną zastawkę mitralną. Średni wiek pacjentów wynosił $67,5 \pm 6,2$ roku. Informacje dotyczące profilaktyki IZW uzyskiwano podczas rutynowych wizyt kardiologicznych. Jednocześnie rozprowadzono ankiety wśród 55 dentystów dotyczące profilaktyki IZW.

Wyniki: Czterdziestu jeden pacjentów $(85,4 \%)$ miało świadomość konieczności stosowania profilaktyki IZW, 28 z nich $(68,2 \%)$ wskazało jedynie zabiegi dentystyczne, 14 z nich $(34,1 \%)$ podało także gastroskopię, kolonoskopię oraz koronarografię, a 18 z nich (43,9\%) wskazało preparaty amoksycyliny. Pięćdziesięciu czterech dentystów (98,2\%) wskazało pacjenta ze sztuczną zastawką jako wymagającego profilaktyki IZW, 41 z 55 (74,5\%) wskazało amoksycylinę lub ampicylinę. Wszyscy dentyści uważali, że należy stosować profilaktykę IZW przed ekstrakcją zęba, 50 (90,9\%) - przy leczeniu kanałowym, 50 (90,9\%) - przy zabiegach w okolicy dziąsła. Zdaniem 10 (18,2\%) profilaktyka IZW nie jest konieczna przy wszczepianiu implantu, a wg 10 (18,2\%) - przy usuwaniu kamienia nazębnego. 
of dentists concerning IE prophylaxis requires verification in accordance with the current guidelines.

Key words: artificial valve, IE prophylaxis, dentist.

\section{Introduction}

For many years, the prophylactic use of antibiotics in patients with heart diseases associated with high risk of infective endocarditis (IE) was a common practice in cardiology and dental care. Despite the progress made in diagnosis and treatment, IE remains a dangerous disease of high mortality [1-3]. At the same time, there is a growing population of patients with artificial valves, in which morbidity and mortality in the occurrence of IE reach several dozen percent [1-3]. Currently, according to the recommendations of the European Society of Cardiology (ESC) of 2009, the only treatments that require prevention are dental treatments involving the rupture of the oral mucosa and gingiva [3]. The cooperation between the patient with an artificial valve and the leading dentist and their knowledge about IE prevention form the basis of mutual relations in the process of diagnosis and treatment of oral diseases.

\section{Material and methods}

The study included 48 patients after artificial heart valve implantation, treated in the Outpatient Cardiology Clinic at the Silesian Centre for Heart Diseases in Zabrze. Demographic characteristics of patients and data on the artificial heart valves are presented in Table I.

Information concerning the types of procedures, before which prophylaxis is recommended, and the type of antibiotic was obtained from patients during routine visits, based on their cardiological history. Questionnaires were distributed among 55 dentists regarding cardiac patient profiles and dental procedures requiring IE prophylaxis as well as the types of recommended antibiotics. The average age of dentists was $35.6 \pm 7.4$ years. The questionnaire form distributed among dentists is presented in Figure 1.

The study was conducted from January 2012 to August 2012.

Tab. I. Demographic characteristics of patients and data on the artificial valves

\begin{tabular}{lc}
\hline Sex & $26 \mathrm{M}, 22 \mathrm{~F}$ \\
\hline Age (years) & $67.5 \pm 6.2$ \\
\hline Time after valve implantation (years) & $4.5 \pm 1.5$ \\
\hline Mechanical aortic valve & $25(52.0 \%)$ \\
\hline Biological aortic valve & $4(8.3 \%)$ \\
\hline Mechanical mitral valve & $18(37.5 \%)$ \\
\hline Biological mitral valve & $1(2.1 \%)$ \\
\hline
\end{tabular}

Wnioski: Duży odsetek pacjentów ze sztuczną zastawką serca jest świadomych stosowania profilaktyki IZW. Wiedza dentystów dotycząca profilaktyki IZW wymaga weryfikacji zgodnie z aktualnymi wytycznymi.

Słowa kluczowe: sztuczna zastawka, profilaktyka IZW, dentysta.

\section{Results}

The results illustrating the current state of IE prophylaxis awareness among patients with artificial heart valves are presented in Table II. Eighteen of 41 patients (43.9\%) indicated preparations of amoxicillin or amoxicillin with clavulanic acid as antibiotic protection against IE, while $23 / 41$ patients $(55.5 \%)$ could not provide the name of the antibiotic. The results demonstrating the current state of knowledge of dentists about the types of cardiac patients requiring IE prevention are presented in Table III.

The types of procedures requiring IE prophylaxis, as indicated by dentists, are shown in Table IV.

Forty-one/55 (74.5\%) dentists indicated preparations of amoxicillin or amoxicillin with clavulanic acid or other penicillin as appropriate antibiotic prophylaxis of IE.

Thirty dentists (54.5\%) reported preparations of clindamycin, while 3 dentists (8.6\%) selected incorrect antibiotic preparations or were unable to determine the name of the drug.

\section{Discussion}

The drastic reduction of IE prevention, associated with the appearance of the ESC guidelines in 2009, results from the lack of scientific evidence on the effectiveness of prevention, the increasing number of invasive procedures, as well as from the possibility of causing the emergence of bacterial strains resistant to antibiotics [1]. Both the ESC and the American Heart Association guidelines from two years previously require the prevention of IE only during dental procedures $[1,3]$. Dental procedures during which one should consider the use of antibiotic prophylaxis are: local periapical treatment of the tooth, tooth extraction, gum treatments, dental implantation and resection of the apex of the tooth, setting up thread retraction, treatments affecting the oral mucosa, and root canal therapy. Antibiotic prophylaxis is not recommended for local anesthesia, removing stitches, introducing orthodontic appliances during healing after shedding of a milk tooth, and treating lip and non-infected mucosa injury [1, 3].

Tab. II. Number of patients with artificial valves stating the need for IE prophylaxis in specific invasive procedures

\begin{tabular}{lc}
\hline Invasive procedures in general & $41(85.4 \%)$ \\
\hline Dental procedures & $\mathbf{2 8 / 4 1 ( 6 8 . 2 \% )}$ \\
\hline Other invasive procedures & \\
\hline - coronarography & $5(12.2 \%)$ \\
\hline - gastroscopy & $11(26.8 \%)$ \\
\hline - colonoscopy & $9(21.9 \%)$ \\
\hline
\end{tabular}



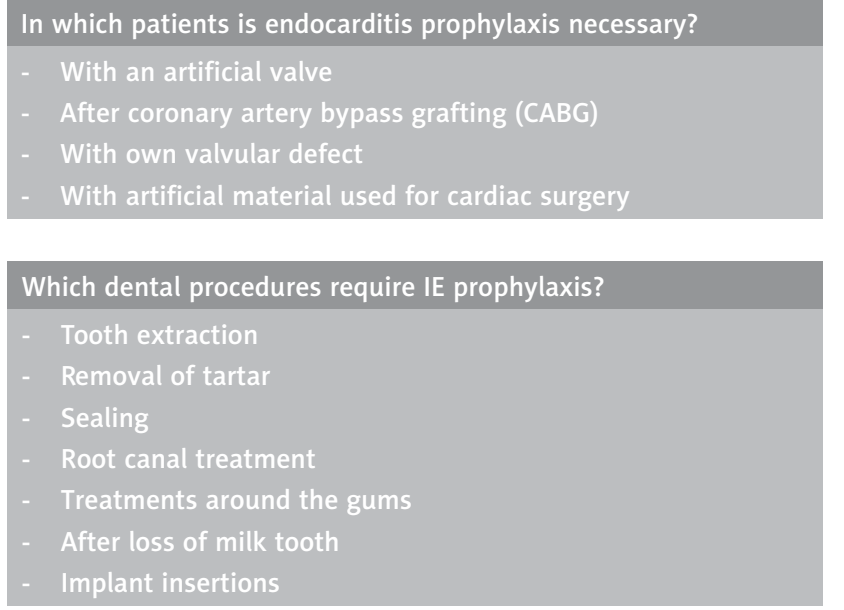

Which antibiotic should be used for the prevention of infective endocarditis?

Fig. 1. Current knowledge of dentists about prevention of infective endocarditis

The first-line antibiotic for IE prophylaxis is currently amoxicillin, and the second-line is clindamycin $[1,3]$. Recommendations in many publications emphasize the importance of daily oral cavity hygiene. It is believed that brushing teeth, or cleaning them with dental floss, can result in the introduction of transient streptococcal bacteremia, which causes a much greater threat than a single tooth extraction [1-4]. It has been proved that the quantitative bacteremia during teeth brushing is increased to $13 \%$, and in the case of full mouth ultrasonic scaling up to $23 \%$ [5].

Many authors emphasize that lack of hygiene and treatment of inflammatory lesions in the mouth result in greater risk than dental procedures [1-4]. The most common microorganisms isolated in blood are: streptococci, enterococci, staphylococci coagulase-negative and Gram-negative bacteria from the HACEK group (Haemophilus, Actinobacillus actinomycetemcomitans, Cardiobacterium hominis, Eikenella and Kingella kingae) residing in the oral cavity.

Van der Meer et al. believe that postoperative bacteremias may bear no relation to dental treatment, and the reasons for their occurrence may include: seeding of bacteria from odontogenic inflammatory foci, everyday oral hygiene procedures, and chewing food. They consider whether the prophylactic use of antibiotics has any beneficial effect $[6,7]$.

Moreover, Wu et al. have demonstrated no greater incidence of IE or increased mortality in patients with chronic teeth infections as compared to those who do not require dental treatment [8].

On the other hand, the use of single doses of antibiotics in the case of IE prevention constitutes a low risk of drug-resistant bacterial strain emergence. In addition, anaphylaxis after administration of $\beta$-lactam antibiotics occurs in 15-40 cases per 100000 and mortality is estimated at 1-3 cases per 100000 . In conclusion, despite the absence of conclusive evidence concerning the role of dental bacte-
Tab. III. Number of dentists stating the need for IE prophylaxis in specific types of cardiac patients

\begin{tabular}{lc}
\multicolumn{2}{c}{ Number of dentists recommending IE prophylaxis } \\
Artificial valve & $54(98.2 \%)$ \\
\hline After coronary artery bypass grafting (CABG) & $45(81.8 \%)$ \\
\hline Own valvular defect & $37(67.3 \%)$ \\
\hline Artificial material used during cardiac surgery & $41(74.5 \%)$ \\
\hline
\end{tabular}

Tab. IV. Types of procedures requiring IE prophylaxis as indicated by dentists

\begin{tabular}{lc}
\multicolumn{2}{c}{ Type of dental treatment } \\
\hline Tooth extraction & $55(100 \%)$ \\
\hline Removal of tartar & $45(81.8 \%)$ \\
\hline Sealing & $22(40.0 \%)$ \\
\hline Root canal treatment & $50(90.9 \%)$ \\
\hline Treatments around the gums & $50(90.9 \%)$ \\
\hline After shedding of a milk tooth & 0 \\
\hline Implant insertions & $45(81.8 \%)$ \\
\hline
\end{tabular}

remia, which is a threat to patients with artificial cardiac valves, antibiotic prophylaxis is now recommended as a standard procedure in these patients. Both during diagnosis and treatment, it is essential for dentists treating patients with artificial valves to be aware of the need for continuous evaluation of the recommended IE prophylaxis. The literature offers limited data concerning IE prevention awareness among patients with prosthetic valves.

In a study of 82 patients with artificial valves, nearly half of the respondents (44\%) were unaware of the need for IE prophylaxis during dental procedures, and most patients could not give the names of recommended antibiotics [9].

In our own study we found that a large proportion of patients with artificial heart valves were aware of IE prophylaxis before dental procedures. About one third of the patients indicated the need for IE prophylaxis prior to invasive procedures other than dental care; nearly half of the patients knew the names of the antibiotics recommended for IE prophylaxis. It follows that patients with artificial heart valves are generally aware of the links between the oral cavity and the presence of artificial material in the heart. By contrast, $34.1 \%$ of patients, in addition to dental and other invasive procedures, identified treatments not necessarily present in the guidelines prior to 2009.

Taking into account the abovementioned data, it appears that some of the patients may not have been informed by cardiologists about cardiac updates in the guidelines.

There are limited data on the current knowledge about dental IE prophylaxis in patients with heart disease. In our study, almost all dentists indicated the need for dental IE prophylaxis in a patient with an artificial valve, while $74.5 \%$ of respondents pointed to amoxicillin formulations or combinations of amoxicillin with clavulanic acid as the recommended antibiotic. A relatively large proportion of dentists pointed to preparations of clindamycin. This is probably due to the fact 
that clindamycin is the most common antibiotic used by dentists. Recall that the ESC recommends the use of clindamycin in the case of amoxicillin / ampicillin allergies. Published data show considerable differences in the percentages of dentists correctly identifying particular patient profiles requiring IE prevention (from $56 \%$ to over $90 \%$ ) [10-12]. Similar differences have been noted in the percentages of dentists correctly identifying the recommended first-line antibiotics (from $56.2 \%$ to $99 \%)[10,11,13]$. As in our study, clindamycin was often indicated by dentists as the recommended form of IE prevention [10]. No upward trend in dental knowledge concerning the prevention of IE in patients with artificial valves was reported in studies published over several years [10-12]. In our study, the dentists appeared to be well informed in regard to the need for IE prophylaxis in patients with artificial valves; only 1 dentist (1.8\%) did not indicate such need for patients with artificial valves. The large majority of dentists pointed incorrectly to patients after CABG (81.8\%), and more than half of them included patients with own valvular defects. This indicates that the current knowledge of dentists concerning the need for IE prophylaxis in patients with artificial heart valves is correct, but they may be less informed in regard to other cardiac stages. Dental procedures that are considered most invasive (such as interventions in the oral mucosa, tooth extractions, root canal treatment, treatments around the gums) were identified as requiring IE prophylaxis by a large percentage of dentists, reaching $100 \%$ of the respondents in the case of tooth extraction. Given the above, it is surprising that a relatively low percentage of the dentists believed in the need for IE prevention before tooth implantation (81.8\%), despite the fairly obvious invasive nature of this surgery. This may be due to the fact that this type of treatment is performed by dentists less frequently. A similar percentage of dentists stated the need for IE prophylaxis during dental tartar removal, possibly due to the dentists' conviction that it is a fairly uncomplicated procedure of low invasiveness. A surprisingly large percentage of dentists indicated IE prophylaxis before sealing. Taking into account the obtained results, it should be stressed that cardiologists treating patients with artificial valves should regularly inform them of the procedures for which IE prophylaxis is currently recommended.

Regardless of the guidelines, it should also be emphasized that the treating cardiologist or dentist should respect the decision of the cardiac patient asking for the use of IE prophylaxis, even if it is not currently recommended in their particular case $[3,14]$.

\section{Conclusions}

A large proportion of patients with artificial heart valves are aware of the need for IE prevention.

The current knowledge of dentists concerning the need for IE prophylaxis in patients with artificial heart valves is correct, but is less satisfactory in regard to other cardiac stages. Tooth extraction was the dental procedure that was most often indicated as requiring IE prophylaxis.

Communication is needed between patients with artificial heart valves and their cardiologists and dentists.

\section{Study limitations}

1. The average time since the valve surgery was $4.5 \pm 1.5$ years. Therefore some patients may have had outdated information on IE prophylaxis.

2. No distinction was made between patients with artificial material used for the correction of valvular and congenital heart diseases.

\section{Literature}

1. Habib G, Hoen B, Tornos P, Thuny F, Prendergast B, Vilacosta I, Moreillon P, de Jesus Antunes M, Thilen U, Lekakis J, Lengyel M, Müller L, Naber CK, Nihoyannopoulos P, Moritz A, Zamorano JL; ESC Committee for Practice Guidelines. Guidelines on the prevention, diagnosis, and treatment of infective endocarditis (new version 2009): the Task Force on the Prevention, Diagnosis, and Treatment of Infective Endocarditis of the European Society of Cardiology (ESC). Endorsed by the European Society of Clinical Microbiology and Infectious Diseases (ESCMID) and the International Society of Chemotherapy (ISC) for Infection and Cancer. Eur Heart J 2009; 30: 2369-2413.

2. NICE Short Clinical Guidelines Technical Team: Prophylaxis against infective endocarditis: antimicrobial prophylaxis against infective endocarditis in adults and children undergoing interventional procedures. London, $\mathrm{Na}$ tional Institute for Health and Clinical Excellence, 2008.

3. Wilson W, Taubert KA, Gewitz M, Lockhart PB, Baddour LM, Levison M, Bolger A, Cabell CH, Takahashi M, Baltimore RS, Newburger JW, Strom BL, Tani LY, Gerber M, Bonow RO, Pallasch T, Shulman ST, Rowley AH, Burns JC, Ferrieri P, Gardner T, Goff D, Durack DT; American Heart Association Rheumatic Fever, Endocarditis, and Kawasaki Disease Committee; American Heart Association Council on Cardiovascular Disease in the Young; American Heart Association Council on Clinical Cardiology; American Heart Association Council on Cardiovascular Surgery and Anesthesia; Quality of Care and Outcomes Research Interdisciplinary Working Group. Prevention of infective endocarditis: guidelines from the American Heart Association: a guideline from the American Heart Association Rheumatic Fever, Endocarditis, and Kawasaki Disease Committee, Council on Cardiovascular Disease in the Young, and the Council on Clinical Cardiology, Council on Cardiovascular Surgery and Anesthesia, and the Quality of Care and Outcomes Research Interdisciplinary Working Group. Circulation 2007; 116: 1736-1754.

4. Farbod F, Kanaan H, Farbod J. Infective endocarditis and antibiotic prophylaxis prior to dental/oral procedures: latest revision to the guidelines by the American Heart Association published April 2007. Int J Oral Maxillofac Surg 2009; 38: 626-631.

5. Kinane DF, Riggio MP, Walker KF, MacKenzie D, Shearer B. Bacteraemia following periodontal procedures. J Clin Periodontol 2005; 32: 708-713.

6. van der Meer JT. Prophylaxis of endocarditis. Neth J Med 2002; 60: 423-427.

7. Van der Meer JT, Van Wijk W, Thompson J, Vandenbroucke JP, Valkenburg HA, Michel MF. Efficacy of antibiotic prophylaxis for prevention of native-valve endocarditis. Lancet 1992; 339: 135-139.

8. Wu GH, Manzon S, Badovinac R, Woo SB. Oral health, dental treatment, and cardiac valve surgery outcomes. Spec Care Dentist 2008; 28: 65-72.

9. Stucki C, Mury R, Bertel O. Insufficient awareness of endocarditis prophylaxis in patients at risk. Swiss Med Wkly 2003; 133: 155-159.

10. Lauber C, Lalh SS, Grace M, Smith MH, MacDougall K, West P, Compton S. Antibiotic prophylaxis practices in dentistry: a survey of dentists and physicians. J Can Dent Assoc 2007; 73: 245.

11. Zadik Y, Marom Y, Levin L. Dental practitioners' knowledge and implementation of the 2007 International Association of Dental Traumatology guidelines for management of dental trauma. Dent Traumatol 2009; 25: 490-493.

12. Ahmadi-Motamayel F, Vaziri S, Roshanaei G. Knowledge of General Dentists and Senior Dental Students in Iran about Prevention of Infective Endocarditis. Chonnam Med J 2012; 48: 15-20.

13. Doshi D, Baldava P, Reddy S, Singh R. Self-reported knowledge and practice of American Heart Association 2007 guidelines for prevention of infective endocarditis: a survey among dentists in Hyperabad City, India. Oral Health Prev Dent 2011; 9: 347-351.

14. Dhoble A, Vedre A, Abdelmoneim SS, Sudini SR, Ghose A, Abela GS, Karve M. Prophylaxis to prevent infective endocarditis: to use or not to use? Clin Cardiol 2009; 32: 429-433. 